\title{
EFEKTIVITAS BIMBINGAN BELAJAR MANDIRI DAN IMPLIKASINYA TERHADAP HASIL BELAJAR PENDIDIKAN AGAMA ISLAM PESERTA DIDIK DI SMK NEGERI 3 GORONTALO
}

\author{
Darmawati Zakaria dan Sulaiman Ibrahim \\ darmawatizakatia4@gmail.com \\ Sulaiman@iaingorotalo.ac.id
}

\begin{abstract}
ABSTRAK
Guru sebagai pembimbing dalam proses pembelajaran membantu setiap peserta didik mengatasi kesulitan belajar baik secara individual maupun kelompok, melalui bimbingan belajar mandiri. Penelitian ini bertujuan untuk mengkaji lebih dalam pelaksanaan bimbingan belajar mandiri dan menganalisis pengaruhnya terhadap hasil belajar peserta didik. Metode yang digunakan adalah pendekatan kualitatif, dengan teknik observasi, wawancara, dan dokumentasi. Hasil penelitian menunjukkan bahwa pelaksanaan bimbingan belajar mandiri di SMK Negeri 3 Gorontalo terdapat 3 proses tahapan yaitu 1) Perencanaan; 2) Pelaksanaan; dan 3) Penilaian, Terbukti besarnya pengaruh terhadap hasil belajar peserta didik yang mengikuti kegiatan proses pembelajaran dengan teknik individual dan kelompok keseluruhannya tuntas belajar (100\%). Teknik individual rerata prosentase baik sekali $57.89 \%$ dan rerata prosentase kriteria baik $42.11 \%$. Sedangkan keberhasilan teknik kelompok rerata prosentase baik sekali $66.67 \%$, dan rerata prosentase kriteria baik $33.33 \%$.
\end{abstract}

Kata Kunci : Bimbingan Belajar Mandiri, Hasil Belajar 
Jurnal Ilmiah Al-Jauhari (JIAJ)

Studi Islam dan Interdisipliner

Volume 3 No 2 September 2018

ISSN 2541-3430 E-ISSN 2541-3449

\section{A. Pendahuluan}

Aktivitas belajar bagi setiap peserta didik, tidak selamanya dapat berlangsung secara wajar. Kadang-kadang lancar, kadang-kadang tidak, kadang-kadang dapat cepat menangkap apa yang dipelajari dan terkadang juga teramat sulit. Dalam hal semangat terkadang semangat tinggi, tetapi juga terkadang sulit untuk mengadakan konsentrasi.

Setiap peserta didik memang tidak ada yang sama, perbedaan individual ini yang menyebabkan perbedaan tingkah laku belajar di kalangan anak didik. Dalam keadaan dimana anak didik tidak dapat belajar sebagai mana mestinya, itulah yang dinamakan kesulitan belajar. Guru sebagai pembimbing dalam proses pembelajaran membantu setiap peserta didik mengatasi masalah-masalah yang dihadapi peserta didik baik secara individual maupun kelompok. ${ }^{1}$

Bimbingan belajar mandiri dipandang dapat membantu guru dalam meningkatkan hasil pembelajaran khususnya pada mata pelajaran Pendidikan Agama Islam, yang merupakan mata pelajaran wajib di SMK dengan memiliki alokasi waktu 3 jam perminggu. ${ }^{2}$ Bimbingan belajar mandiri menyebabkan peserta didik memiliki inisiatif, dengan atau tanpa bantuan orang lain, untuk menganalisis kebutuhan belajarnya sendiri, merumuskan tujuan belajarnya sendiri, mengidentifikasi sumber-sumber belajar, memilih dan melaksanakan strategi belajar yang sesuai serta mengevaluasi prestasi belajarnya sendiri. Belajar mandiri tidak berarti belajar sendiri. ${ }^{3}$

${ }^{1}$ Abu Ahmadi dan Widodo Supriono, Pskologi Belajar (edisi revisi). (Jakarta: Rineka Cipta. 2004), h. 115-117

22 Peraturan Menteri Pendidikan dan Kebudayaan Nomor 69 Tahun 2013, Kerangka Dasar dan Struktur Kurikulum Sekolah Menengah Atas/ Madrasah Aliyah, h. 9.

${ }^{3}$ Astawan I Gede, Model-Model Pembelajaran Inovatif, (Singaraja: Universitas Pendidikan Ganesha, 2010), h. 61. 
Jurnal Ilmiah Al-Jauhari (JIAJ)

Studi Islam dan Interdisipliner

Volume 3 No 2 September 2018

ISSN 2541-3430 E-ISSN 2541-3449

Belajar mandiri bukan merupakan usaha untuk mengasingkan peserta didik dari teman belajarnya atau gurunya. ${ }^{4}$ Hal terpenting dalam proses belajar mandiri ialah peningkatan kemampuan dan keterampilan peserta didik dalam proses belajar tanpa bantuan orang lain, sehingga pada akhirnya peserta didik tidak tergantung pada guru, teman atau orang lain. Dalam belajar mandiri peserta didik akan berusaha sendiri dahulu untuk memahami materi pelajaran yang dibaca atau dipelajarinya. Kalau mendapat kesulitan barulah peserta didik akan bertanya atau mendiskusikan dengan teman, guru atau orang lain. Peserta didik mandiri akan mampu mencari sumber belajar yang dibutuhkan.

Bimbingan belajar mandiri akan memberdayakan peserta didik bahwa belajar adalah tanggung jawab mereka sendiri dan guru hanya berperan sebagai fasilitator dan motivator dalam kegiatan pembelajaran sehingga proses belajar yang dilakukan juga optimal yang berimbas pada peningkatan kemandirian belajar dan prestasi belajar peserta didik.

Berdasarkan hasil observasi awal bahwa pelaksanaan bimbingan belajar mandiri pada mata pelajaran Pendidikan Agama Islam di SMK Negeri 3 Gorontalo, dilaksanakan secara individual maupun kelompok. Pada saat guru memberikan LKPD (Lembar Kerja Peserta Didik) kepada masing-masing peserta didik untuk mengetahui tingkat kemampuan peserta didik, guru membimbing secara individual cara menyelesaikan tugas, memanfaatkan waktu yang telah ditetapkan, menggunakan buku pelajaran, memberikan penguatan dengan memberi kesempatan kepada masing-masing peserta didik menggunakan strateginya sendiri dalam menyelesaikan tugas. Terlihat bahwa siswa tekun mengerjakan tugas dan tidak berhenti sebelum pekerjaannya selesai, ulet menghadapi tugas, menunjukkan minat dalam belajar, senang bekerja sendiri, serta bertanggung jawab. Secara kelompok terlihat pada kegiatan diskusi, guru menciptakan kesiapan peserta didik, memberikan motivasi, mengarahkan dilatih untuk berpatisipasi

\footnotetext{
${ }^{4}$ http;/www.pustekkom.co.id/teknodik/tl3/isi.htm., diakses 04-11-2017.
} 
Jurnal IImiah Al-Jauhari (JIAJ)

Studi Islam dan Interdisipliner

Volume 3 No 2 September 2018

ISSN 2541-3430 E-ISSN 2541-3449

aktif mengemukakan pendapat terhadap materi yang dibahas berdasarkan pengetahuan dan pengalamannya, hal tersebut membuat peserta didik terlibat dalam suasana yang tumbuh dan berkembang dalam kelompok.

Mengingat bimbingan belajar mandiri merupakan proses pemberian bantuan dari guru PAI kepada peserta didik dengan cara mengembangkan suasana belajar yang kondusif, agar pencapaian hasil belajar yang diperoleh optimal. Oleh sebab itu, perlu diadakan peneltitian tentang bagaimana pelaksanaan bimbingan belajar mandiri baik secara individu maupun kelompok, dan implikasinya terhadap peningkatan hasil belajar peserta didik di SMK Negeri 3 Gorontalo. 


\section{Jurnal IImiah Al-Jauhari (JIAJ) \\ Studi Islam dan Interdisipliner \\ Volume 3 No 2 September 2018 \\ ISSN 2541-3430 E-ISSN 2541-3449}

\section{B. Kajian Teori}

\section{Belajar Mandiri}

Pada kurikulum 2013 ini, guru dituntut untuk mengembangkan situasi belajar yang memungkinkan setiap peserta didik bekerja dengan kemampuan masing-masing pada setiap pelajaran dan guru diminta untuk menguasahakan keterlibatan peserta didik dalam berbagai kegiatan pembelajaran. ${ }^{5}$ Dengan demikian dapat diketahui bahwa kurikulum 2013 kini lebih mengutamakan keaktifan dan partisipasi peserta didik dalam pembelajaran. Jadi peserta didik lebih dilatih untuk dapat belajar mandiri, lebih aktif, dan kreatif untuk menentukan tujuan belajarnya sesuai dengan nilai-nilai karakter dan akhlak mulia

Pengertian belajar mandiri menurut Hiemstra adalah sebagai berikut:

a. Setiap individu berusaha meningkatkan tanggung jawab untuk mengambil berbagai keputusan.

b. Belajar mandiri dipandang sebagai suatu sifat yang sudah ada pada setiap orang dan situasi pembelajaran.

c. Belajar mandiri bukan berarti memisahkan diri dengan orang lain.

d. Dengan belajar mandiri, peserta didik dapat mentransferkan hasil belajarnya yang berupa pengetahuan dan keterampilan ke dalam situasi yang lain.

e. Peserta didik yang melakukan belajar mandiri dapat melibatkan berbagai sumber daya dan aktivitas, seperti: membaca sendiri, belajar kelompok, latihan-latihan, dialog elektronik, dan kegiatan korespondensi.

f. Peran efektif guru dalam belajar mandiri masih dimungkinkan, seperti dialog dengan peserta didik, pencarian sumber, mengevaluasi hasil, dan memberi gagasan-gagasan kreatif. ${ }^{6}$

Belajar mandiri menurut Hiemstra di atas, adalah perilaku peserta didik dalam mewujudkan kehendak atau keinginannya secara nyata dengan tidak bergantung pada orang

${ }^{5}$ Mulyasa, Pengembangan dan Implementasi kurikulum 2013, (Bandung:PT. Remaja Rosdakarya), h. 43

${ }^{6}$ Hiemstra, Self-Directed Learning. In T. Husen \& T. N. Postlewaite (Eds), The International Encyclopedia of Education (second edition), (Oxford: Porgomon Press. 1994), h. 1 


\section{Jurnal IImiah Al-Jauhari (JIAJ) \\ Studi Islam dan Interdisipliner \\ Volume 3 No 2 September 2018 \\ ISSN 2541-3430 E-ISSN 2541-3449}

lain, dalam hal ini adalah peserta didik tersebut mampu melakukan belajar sendiri, dapat menentukan cara belajar yang efektif, mampu melaksanakan tugas-tugas belajar dengan baik dan mampu untuk melakukan aktivitas belajar secara mandiri.

Knowless menjelaskan bahwa, belajar mandiri adalah suatu proses dimana individu mengambil inisiatif dengan atau tanpa bantuan dari orang lain untuk mendiagnosa kebutuhan belajarnya sendiri, merumuskan atau menentukan tujuan belajarnya sendiri, mengidentifikasi sumber-sumber belajar, memilih dan melaksanakan strategi belajarnya, serta mengevaluasi hasil belajarnya sendiri. ${ }^{7}$

Pengertian belajar mandiri menurut Rusman yang dikutip dari beberapa akhli seperti Wedemeyer adalah peserta didik yang belajar secara mandiri mempunyai kebebasan untuk belajar tanpa harus menghadiri pembelajaran yang diberikan oleh pendidik di kelas. Menurut Kozma, Belle,Williams yang dikutip oleh Rusman mendefinisikan bahwa belajar mandiri adalah sebagai usaha individu peserta didik yang bersifat otomatis untuk mencapai kompetensi akademis tertentu. ${ }^{8}$

Haris Mujiman, mengemukakan bahwa belajar mandiri adalah kegiatan belajar yang diawali dengan kesadaran adanya masalah, disusul dengan timbulnya niat melakukan kegiatan belajar secara sengaja untuk menguasai sesuatu kompetensi yang diperlukan guna mengatasi masalah. ${ }^{9}$ Penetapan kompetensi sebagai tujuan belajar, dan cara pencapaiannya baik penetapan waktu belajar, tempat belajar, irama belajar, tempo belajar, cara belajar, maupun evaluasi belajar dilakukan oleh peserta didik sendiri. Di sini belajar mandiri lebih dimaknai sebagai usaha peserta didik untuk melakukan kegiatan belajar yang didasari oleh niatnya untuk menguasai suatu kompetensi tertentu.

Dari pengertian di atas, dapat diperoleh gambaran bahwa seseorang yang sedang menjalankan kegiatan belajar mandiri lebih ditandai, dan ditentukan, oleh motif yang mendorongnya belajar. Bukan oleh kenampakan fisik kegiatan belajarnya. Pembelajar tersebut secara fisik bisa sedang belajar sendirian, belajar kelompok atau bahkan sedang

\footnotetext{
${ }^{7}$ http://pustekkom.depdiknas.go.id/index.php, diakses Tanggal 05 Januari 2017

${ }^{8}$ Rusman, Model-Model PembelajaranMengembangkan Profesionalisme Guru edisi ke-2, (Jakarta: Raja Grafindo Persada,2014 ), h. 356.

${ }^{9}$ Haris Mudjiman, Belajar Mandiri, (Surakarta : UNS Press, 2008), h. 1.
} 


\section{Jurnal IImiah Al-Jauhari (JIAJ) \\ Studi Islam dan Interdisipliner \\ Volume 3 No 2 September 2018 \\ ISSN 2541-3430 E-ISSN 2541-3449}

dalam situasi belajar klasikal dalam kelas. Akan tetapi, bila motif yang mendorong kegiatan belajarnya adalah motif untuk menguasai sesuatu kompetensi yang peserta didik inginkan, maka peserta didik sedang menjalankan belajar mandiri.

Anatomi konsep belajar mandiri bila disederhanakan terdiri atas kepemilikan kompetensi tertentu sebagai tujuan belajar; belajar aktif sebagai strategi belajar; keberadaan motivasi belajar sebagai prasyarat berlangsungnya kegiatan belajar; dan paradigma kontruktivisme sebagai landasan konsep. ${ }^{10}$

Adapun tujuan dari bimbingan belajar mandiri yaitu:

a) Agar peserta didik bertanggung jawab menilai kemampuannya sendiri dan menggunakan pengetahuan mereka secara efektif bagi dirinya.

b) Agar peserta didik menjalani kehidupannya sekarang secara efektif dan menyiapkan dasar kehidupan masa depannya sendiri.

c) Agar semua potensi peserta didik berkembang secara optimal meliputi semua aspek pribadinya sebagai individu yang potensial. ${ }^{11}$

Abu Ahmadi dan Widodo Supriono, menjelaskan bahwa tujuan bimbingan belajar adalah :

a) Mencarikan cara-cara belajar yang efisien dan efektif bagi seorang anak atau kelompok anak.

b) Menunjukan cara-cara mempelajari sesuai dan menggunakan buku pelajaran

c) Membuat tugas sekolah dan mempersiapkan diri dalam ulangan dan ujian.

d) Memilih suatu bidang studi sesuai bakat, minat, kecerdasan, cita-cita, dan kondisi fisik atau kesehatannya.

e) Menunjukan cara-cara menghadapi kesulitan dalam bidang studi tertentu.

f) Menentukan pembagian waktu dan perencanaan jadwal belajarnya.

g) Memilih pelajaran tambahan baik yang berhubungan dengan pelajaran di sekolah maupun untuk pengembangan bakat dan kariernya di masa depan. ${ }^{12}$

\footnotetext{
${ }^{10}$ Ibid., h. 4.

${ }^{11}$ Ibid., h. 195.
} 


\section{Jurnal IImiah Al-Jauhari (JIAJ) \\ Studi Islam dan Interdisipliner \\ Volume 3 No 2 September 2018 \\ ISSN 2541-3430 E-ISSN 2541-3449}

Menurut Gea mengatakan bahwa individu dikatakan mandiri apabila memiliki lima ciri sebagai berikut: 1) percaya diri, 2) mampu bekerja sendiri, 3) menguasai keahlian dan keterampilan yang sesuai dengan kerjanya, 4) menghargai waktu, dan 5) tanggung jawab. ${ }^{13}$ Kelima ciri-ciri individu mandiri tersebut, dapat dijelaskan oleh penulis sebagai berikut: 1) percaya diri, adalah meyakini pada kemampuan dan penilaian diri sendiri dalam melakukan tugas dan memilih pendekatan yang efektif, 2) mampu bekerja sendiri, adalah usaha sekuat tenaga yang dilakukan secara mandiri untuk menghasilkan sesuatu yang membanggakan atas kesungguhan dankeahlian yang dimilikinya. 3) menguasai keahlian dan keterampilan yang sesuai dengan kerjanya, adalah mempunyai keterampilan sesuai dengan potensi yang sangat diharapkan pada lingkungan kerjanya. 4) menghargai waktu, adalah kemampuan mengatur jadwal sehari-hari yang diprioritaskan dalam kegiatan yang bermanfaat secara efesien, dan 5) tanggung jawab, adalah segala sesuatu yang harus dijalankan atau dilakukan oleh seseorang dalam melaksanakan sesuatu yang sudah menjadi pilihannya atau dengan kata lain, tanggung jawab merupakan sebuah amanat atau tugas dari seseorang yang dipercayakan untuk menjaganya.

Peserta didik yang mempunyai kemandirian belajar dapat dilihat dari kegiatan belajarnya, dia tidak perlu disuruh bila belajar dan kegiatan belajar dilaksanakan atas inisiatif dirinya sendiri. Untuk mengetahui apakah peserta didik itu mempunyai kemandirian belajar maka perlu diketahui ciri- ciri kemandirian belajar.

Menurut Basri, bahwa ciri-ciri kemandirian belajar meliputi :
a) Peserta didik merencanakan dan memilih kegiatan belajar sendiri.
b) Peserta didik berinisiatif dan memacu diri untuk belajar terus menerus.
c) Peserta didik dituntut tanggung jawab dalam belajar.

\footnotetext{
${ }^{12}$ Abu Ahmadi \& Widodo Supriono, Psikologi Belajar, (Jakarta: Rineka Cipta, 2004), h. 111112.

${ }^{13} 1$ A.Atosakhi, Gea, dkk, Character Building 1 Relasi dengan Diri Sendiri (edisi revisi). (Jakarta: Elex Media Komputindo, 2003), h. 195.
} 


\section{Jurnal IImiah Al-Jauhari (JIAJ) \\ Studi Islam dan Interdisipliner \\ Volume 3 No 2 September 2018 \\ ISSN 2541-3430 E-ISSN 2541-3449}

d) Peserta didik belajar secara kritis, logis, dan penuh keterbukaan.

e) Peserta didik belajar dengan penuh percaya diri. ${ }^{14}$

Dengan memperhatikan ciri-ciri di atas, dapat dikatakan bahwa belajar mandiri tidak berpatokan pada suatu aturan. Jadi tidak ada aturan khusus yang membelenggu peserta didik dalam belajar mandiri. Peserta didik bebas/fleksibel mengatur segala urusan untuk belajarnya secara mandiri dan dapat disesuaikan dengan minat, motivasi, dan kemampuan masing-masing individu. Jadi untuk masing-masing Peserta didik atau individu memiliki cara, tujuan, dan proses yang berbeda-beda. Belajar mandiri dapat melatih Peserta didik untuk menganalisis kebutuhan yang dia butuhkan dan bagaimana cara memenuhinya, khususnya dalam hal belajar. Jadi belajar mandiri sangat memudahkan Peserta didik untuk belajar sesuai keinginannya.

\section{Bimbingan Belajar}

Setiap peserta didik dalam kehidupannya baik sebagai pribadi maupun sebagai anggota masyarakat memiliki masalah. Masalah peserta didik di sekolah ada yang disebabkan oleh kondisi dalam diri peserta didik sendiri dan ada yang disebabkan oleh kondisi dariluar diri peserta didik. Oleh karena itu beberapa aspek-aspek masalah belajar yang memerlukan bimbingan belajar seperti berikut:

a. Keterlambatan akademik, yaitu keadaan peserta didik yang diperkirakan memiliki intelegensi yang cukup tinggi, tetapi tidak dapat memanfaatkan secara optimal.

b. Ketercepatan dalam belajar, yaitu keadaan anak yang memiliki bakat akademik yang cukup tinggi, tetapi masih memerlukan tugas-tugas khusus untuk memenuhi kebutuhan belajarnya.

c. Sangat lambat dalam belajar, yaitu keadaan anak yang memiliki bakat akademik yang kurang memadai dan perlu mempertimbangkan untuk mendapatkan pendidikan.

Hasan Basri, Remaja Berkualitas (Problematika Remaja dan Solusinya). (Yogyakarta: Pustaka Pelajar, 2004), h. 64 


\section{Jurnal IImiah Al-Jauhari (JIAJ) \\ Studi Islam dan Interdisipliner \\ Volume 3 No 2 September 2018 \\ ISSN 2541-3430 E-ISSN 2541-3449}

d. Kurang motivasi dalam belajar, yaitu keadaan anak yang kurang bersemangat dan malas belajar.

e. Bersikap dan berkebiasaan buruk dalam belajar, yaitu keadaan peserta didik yang suka menunda tugas-tugas yang diberikan seorang guru, tidak mau bertanya untuk hal-hal yang tidak diketahuinya, dan sebagainya. ${ }^{15}$

Cara mengatasi berbagai macam permasalahan dalam belajar, dapat dilakukan dengan menggunakan dua teknik yaitu:

a. Teknik Individu, yaitu suatu bantuan yang diberikan kepada seseorang secara langsung. Dalam cara ini pemberian bantuan dilaksanakan secara face to face relationship (hubungan muka ke muka, atau hubungan empat mata. Ada beberapa teknik bimbingan individu di antaranya adalah:

1) Bimbingan Direktif (Direktif Counseling) : teknik ini yang paling berperan adalah pembimbing. Dalam prakteknya pembimbing berusaha mengarahkan peserta didik sesuai dengan masalahnya. Selain itu, pembimbing juga memberikan saran, anjuran, dan nasihat (motivasi) kepada peserta didik.

2) Bimbingan non-direktif teknik ini peserta didik diberikan peranan utama dalam bidang interaksi dalam bimbingan, seorang pembimbing hanya menampung pembicaraan yang berperan aktif adalah peserta didik itu sendiri. Pelayanan bimbingan dengan teknik non-direktif lebih difokuskan pada peserta didik yang bermasalah.

3) Bimbingan Efektif yaitu teknik bimbingan yang digunakan secara kombinasi atau bergantian menurut keperluannya. Agar pembimbing berhasil secara efektif dan efisien

\footnotetext{
${ }^{15}$ Prayitno dan Erman Amti, Dasar-Dasar bimbingan dan Konseling, (Jakarta: Rineka Cipta, 2004), h.
} 280. 


\section{Metode Penelitian}

Penelitian ini merupakan jenis penelitian kualitatif (qualitative research), yaitu suatu proses penelitian yang dilakukan secara wajar dan natural sesuai dengan kondisi obyektif di lapangan tanpa adanya manipulasi. ${ }^{16}$ Sumber data dalam penelitian ini dibagi atas dua jenis:

1. Data Primer, merupakan data utama yang diambil langsung dari para informan, yang dalam hal ini adalah guru Pendidikan Agama Islam dan siswa.

2. Data Sekunder, yaitu pengambilan data dalam bentuk dokumen-dokumen yang telah ada serta hasil penelitian yang ditemukan peneliti secara tidak langsung. Data ini berupa dokumentasi penting menyangkut profil SMK Negeri 3 Gorontalo, RPP Guru Pendidikan Agama Islam dan Budi Pekerti serta administrasi lainnya yang relevan dengan topik kajian pada penelitian ini

Dalam pengumpulan data menggunakan metode :

1. Observasi yaitu cara pengumpulan data yang dilakukan dengan cara mengamati dan mengkaji tingkah laku atau keadaan yang akan diteliti sambil berperan serta dalam aktivitasnya. Pengamatan yang dimaksudkan adalah pengamatan langsung, ala miah, berpartisipasi, dan bebas.

2. Wawancara (interview) melalui pertanyaan-pertanyaan yang dapat menunjang atau memenuhi informasi yang peneliti butuhkan berdasarkan fokus masalah yang diteliti. Setiap pertanyaan yang diajukan diharapkan dapat mendukung informasi yang dibutuhkan untuk menjawab rumusan masalah penelitian ini.

3. Dokumentasi yaitu cara pengumpulan data dengan mencatat dan mengumpulkan dokumen-dokumen yang dibutuhkan.

\footnotetext{
${ }^{16}$ Zainal Arifin, Penelitian Pendidikan Metode dan Paradigma Baru, (Bandung: Remaja Rosdakarya,
} 2011), h. 140 
Jurnal Ilmiah Al-Jauhari (JIAJ)

Studi Islam dan Interdisipliner

Volume 3 No 2 September 2018

ISSN 2541-3430 E-ISSN 2541-3449

\section{Hasil Penelitian dan Pembahasan}

Kepala SMK Negeri 3 Gorontalo menjelaskan bahwa dalam pelaksanaan pembelajaran terdapat 3 proses tahapan yaitu perencanaan, pelaksanaan dan evaluasi/penilaian. Guru wajib membuat RPP (Rencana Pelaksanaan Pembelajaran) yaitu kegiatan tatap muka untuk satu pertemuan atau lebih. RPP dikembangkan dari silabus untuk mengarahkan kegiatan pembelajaran peserta didik dalam upaya mencapai Kompetensi Dasar. Kemudian selanjutnya melaksanakan proses pembelajaran sesuai RPP dan jadwal yang telah ditetapkan oleh pihak sekolah, dan terakhir mengevaluasi pembelajaran. Sekarang ini SMK 3 Gorontalo telah menerapkan MPD (Manajement Penilaian Digital) yaitu sistem penilaian aplikasi komprehensif (menyeluruh) yang dikeluarkan oleh pihak Direktorat Pembinaan SMK. Setiap guru membuat laporan capaian kompetensi dari para peserta didik melalui aplikasi MPD.

\section{Teknik Individual}

Berdasarkan hasil Observasi dan dokumentasi peneliti pada hari Senin 22 Januari 2018 bahwa pelaksanaan bimbingan belajar mandiri pada mata pelajaran Pendidikan Agama Islam di SMK Negeri 3 Gorontalo, mengacu pada Rencana Pelaksanaan Pembelajaran. Hasil pengamatan kegiatan pembelajaran yang diperoleh $80,77 \%$ kriteria sangat baik (SB), dan 19,23 kriteria baik (B), sedangkan yang memperoleh nilai dengan kriteria cukup dan kurang tidak ditemukan.

Penilaian keberhasilan belajar peserta didik selama mengikuti proses pembelajaran di kelas dilakukan berdasarkan prosedur penilaian pada RPP, sebagaimana pada tabel di bawah ini : 
Tabel 1

Hasil Penilaian Individual

\begin{tabular}{|c|c|c|c|c|c|c|c|c|c|c|}
\hline 1 & ABDUL AZIS A. HABU & 10 & 10 & 20 & 25 & 20 & 85 & 85 & V & - \\
\hline 2 & ABDUL RAIS BOTUTIHE & 8 & 10 & 25 & 25 & 20 & 88 & 88 & V & - \\
\hline 3 & ADIT SAPUTRA ALI & 10 & 15 & 25 & 25 & 20 & 95 & 95 & V & - \\
\hline 4 & ADITYA YUSUF & 10 & 15 & 20 & 25 & 20 & 90 & 90 & V & - \\
\hline 5 & ADRIAN HASAN & 10 & 15 & 25 & 25 & 25 & 100 & 100 & V & - \\
\hline 6 & DAVID DALANGGO & 10 & 10 & 20 & 25 & 20 & 85 & 85 & V & - \\
\hline 7 & DINDA H. MUHSIN & 10 & 15 & 20 & 25 & 20 & 90 & 90 & V & - \\
\hline 8 & FERLENA LAMUSU & 10 & 15 & 25 & 25 & 25 & 100 & 100 & V & - \\
\hline 9 & HARMAIN AGUNE & 10 & 10 & 20 & 25 & 20 & 85 & 85 & V & - \\
\hline 10 & MOH. FADEL DJAFAR & 10 & 15 & 20 & 25 & 20 & 90 & 90 & V & - \\
\hline 11 & MOHAMAD BINJEN & 8 & 15 & 20 & 25 & 20 & 88 & 88 & V & - \\
\hline 12 & MOH. BINTANG ARSYAD & 10 & 15 & 25 & 25 & 25 & 100 & 100 & V & - \\
\hline 13 & RAHMAT LAUDENGI & 10 & 10 & 20 & 25 & 20 & 85 & 85 & V & - \\
\hline 14 & RISKI MOOTALU & 8 & 15 & 20 & 25 & 20 & 88 & 88 & V & - \\
\hline 15 & RIZKY FERDIANSYAH TALANGI & 10 & 15 & 20 & 25 & 20 & 90 & 90 & V & - \\
\hline 16 & SAMSUL NURMUNANDAR WAHIDJI & 8 & 10 & 25 & 25 & 20 & 88 & 88 & V & - \\
\hline 17 & SANDI TUNA & 10 & 15 & 25 & 25 & 20 & 95 & 95 & V & - \\
\hline 18 & SATRIA WIRA ADHI P. RAHAWARIN & 10 & 15 & 25 & 25 & 25 & 100 & 100 & V & - \\
\hline 19 & ZUL FIKRI BOUTI & 8 & 15 & 25 & 25 & 25 & 98 & 98 & V & - \\
\hline & JLH SKOR & 180 & 255 & 425 & 475 & 405 & \multirow{2}{*}{\multicolumn{2}{|c|}{$\begin{array}{c}\text { JUMLAH } \\
\text { NILAI }\end{array}$}} & \multirow{2}{*}{1740} & \multirow{3}{*}{$\begin{array}{c}\text { TUNTAS } \\
100 \%\end{array}$} \\
\hline & JLH SKOR IDEAL & 190 & 285 & 475 & 475 & 475 & & & & \\
\hline & SKOR CAPAIAN $\%$ & 95 & 89 & 89 & 100 & 85 & \multirow{2}{*}{\multicolumn{2}{|c|}{ DASER }} & \multirow{2}{*}{$92 \%$} & \\
\hline & KEGAGALAN \% & 5 & 11 & 11 & - & 15 & & & & GAGAL \\
\hline & KETERANGAN & & & & & & \multicolumn{2}{|c|}{ RATA-RATA } & 91.58 & $0 \%$ \\
\hline
\end{tabular}

Keterangan :

Soal Tuntas

$: 1,2,3,4,5$

Soal Tidak Tuntas

Kegagalan

:Materi soal dibimbing oleh guru

Kelas X Biskonpro-1 Tahun 2018 
Jurnal Ilmiah Al-Jauhari (JIAJ)

Studi Islam dan Interdisipliner

Volume 3 No 2 September 2018

ISSN 2541-3430 E-ISSN 2541-3449

Berdasarkan tabel di atas, dari 19 peserta didik yang mengikuti kegiatan proses pembelajaran pada hari Senin Tanggal 22 Januari 2018 keseluruhannya tuntas belajar (100\%), bahkan hasil capaian melebihi KKM yang telah ditetapkan.Tingkat keberhasilan teknik individual bimbingan belajar mandiri sebagai berikut :

Tabel 2

Keberhasilan Teknik Individual Bimbingan Belajar Mandiri

\begin{tabular}{|c|c|c|c|c|c|}
\hline No & $\begin{array}{c}\text { Rentang } \\
\text { nilai }\end{array}$ & $\begin{array}{c}\text { Jumlah } \\
\text { Peserta }\end{array}$ & Prosentase & Kriteria & $\begin{array}{c}\text { Tuntas/ } \\
\text { Tidak }\end{array}$ \\
\hline
\end{tabular}

\begin{tabular}{|c|c|c|c|c|c|}
\hline & & didik & & & \\
\hline 1 & $90-100$ & 11 & $57.89 \%$ & BS & Tuntas \\
2 & $78-89$ & 8 & $42.11 \%$ & B & Tuntas \\
3 & $60-77$ & - & - & C & Tidak \\
4 & $40-59$ & - & - & K & Tidak \\
5 & $0-39$ & - & - & KS & Tidak \\
\hline & & 19 & $100 \%$ & & \\
\hline
\end{tabular}

Tabel 2 menunjukkan bahwa hasil penilaian kegiatan pembelajaran menunjukkan bahwa seluruh peserta didik yang dibimbing telah tuntas belajar. Dengan demikian, dapat disimpulkan bahwa proses pembelajaran yang dilakukan oleh guru dengan teknik individual bimbingan belajar mandiri telah menunjukkan keberhasilan karena rerata prosentase baik sekali $(57.89 \%)$ dan rerata prosentase kriteria baik (42.11 \%). Bahkan sudah melebih KKM yang ditetapkan 78. Keberhasilan teknik individual bimbingan belajar mandiri lebih jelasnya digambarkan dalam diagram berikut ini: 


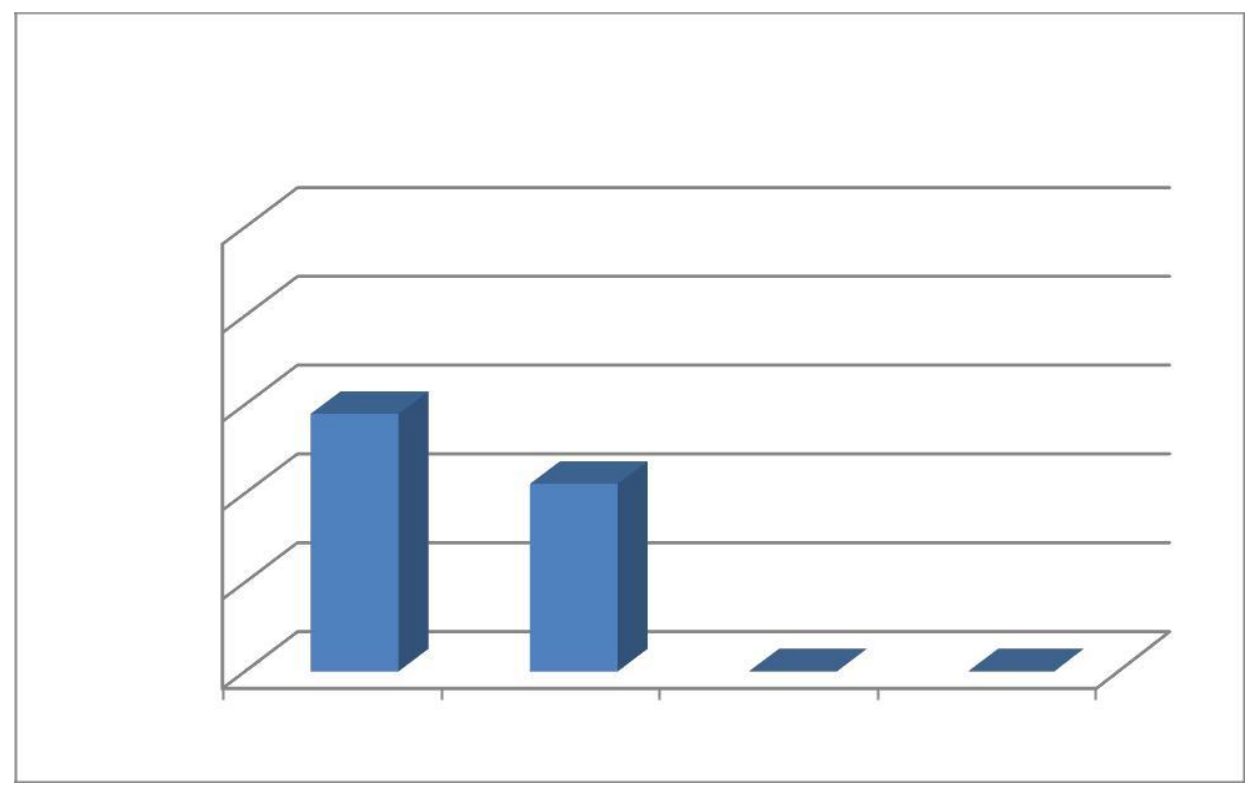

Berdasarkan diagram 1, diasumsikan apabila jumlah nilai memberikan skor yang sama dengan asumsi ideal yaitu skor tertinggi 100, maka prosentase sangat baik mencapai 100\%. Namun demikian, sudah jelas bahwa 100\% peserta didik tuntas belajar, sehingga tidak perlu lagi pelaksanaan remedial.

\section{Teknik Kelompok}

Hasil pengamatan aktivitas selama proses pembelajaran menunjukkan bahwa

bimbingan belajar mandiri teknik kelompok sama halnya dengan teknik individual dapat dilaksanakan dengan sangat baik. $76.92 \%$ memperoleh nilai pengamatan dengan kriteria sangat baik (SB), dan $23.08 \%$ mencapai kriteria baik (B).

Untuk penilaian kelompok, guru dapat memberi nilai sama untuk tiap anggota. Jadi nilai kelompok untuk seluruh anggotanya. Penilaian kelompok sama halnya dengan penilaian individual dilakukan berdasarkan prosedur penilaian pada RPP. 
Jurnal IImiah Al-Jauhari (JIAJ)

Studi Islam dan Interdisipliner

Volume 3 No 2 September 2018

ISSN 2541-3430 E-ISSN 2541-3449

\section{E. Kesimpulan dan Saran}

\section{Kesimpulan}

a. Implementasi bimbingan belajar mandiri di SMK Negeri 3 Gorontalo dilaksanakan dengan teknik individual dan teknik Kelompok. Hal ini dapat meningkatan hasil belajar peserta didik.

b. Keberhasilan pelaksanaan bimbingan belajar mandiri teknik individual rerata prosentase baik sekali $57.89 \%$ dan rerata prosentase kriteria baik $42.11 \%$. Sedangkan keberhasilan teknik kelompok rerata prosentase baik sekali $66.67 \%$, dan rerata prosentase kriteria baik 33.33\%. Hal ini menunjukkan bahwa $100 \%$ peserta didik yang mengikuti proses pembelajaran bimbingan belajar mandiri tuntas belajar. Ketuntasan belajar adalah hasil dari hasil belajar peserta didik.

\section{Saran}

a. Guru dituntut untuk dapat menumbuhkan niat dan motivasi dalam diri peserta serta melakukan pendekatan artinya, guru harus mampu memperhatikan aspek-aspek permasalahan peserta didik agar supaya guru lebih mudah untuk memberikan bantuan scara optimale

b. Sekolah perlu memberikan pelayanan pendidikan yang lebih maksimal dalam upaya peningkatan hasil belajar peserta didik 
Jurnal Ilmiah Al-Jauhari (JIAJ)

Studi Islam dan Interdisipliner

Volume 3 No 2 September 2018

ISSN 2541-3430 E-ISSN 2541-3449

\section{DAFTAR PUSTAKA}

Ahmadi, Abu dan Widodo Supriono, Pskologi Belajar (edisi revisi). Jakarta: Rineka Cipta. 2004.

\& Ahmad Rohani, Bimbingan dan Konseling di Sekolah, Jakarta: Rineka Cipta, 1991.

Arifin, Zainal, Penelitian Pendidikan Metode dan Paradigma Baru, Bandung: Remaja Rosdakarya, 2011.

Atosakhi, Gea, dkk, Character Building 1 Relasi dengan Diri Sendiri (edisi revisi).

Jakarta: Elex Media Komputindo, 2003.

Basri, Hasan, Remaja Berkualitas (Problematika Remaja dan Solusinya). Yogyakarta:

Pustaka Pelajar, 2004.

Direktorat Pendidikan Agama Islam Direktorat Jendral Pendidikan Islam Kementrian Agama RI kerja sama dengan Fakultas tarbiyah IAIN Walisongo, Modul Peningkatan Kualitas Guru (PKG), Semarang, 2011.

Hiemstra, Self-Directed Learning. In T. Husen \& T. N. Postlewaite (Eds), The International Encyclopedia of Education (second edition), Oxford: Porgomon Press. 1994.

I Gede, Astawan, Model-Model Pembelajaran Inovatif, Singaraja: Universitas

Pendidikan Ganesha, 2010.

Mudjiman, Haris, Belajar Mandiri, Surakarta : UNS Press, 2008.

Mulyasa, Pengembangan dan Implementasi kurikulum 2013, Bandung: Remaja

Rosdakarya, 2013.

Peraturan Menteri Pendidikan dan Kebudayaan Nomor 69 Tahun 2013, Kerangka Dasar dan Struktur Kurikulum Sekolah Menengah Atas/ Madrasah Aliyah. 
Jurnal Ilmiah Al-Jauhari (JIAJ)

Studi Islam dan Interdisipliner

Volume 3 No 2 September 2018

ISSN 2541-3430 E-ISSN 2541-3449

Peraturan Menteri Pendidikan dan Kebudayaan No. 66 tahun 2013 tentang Standar Penilaian Pendidikan.

Prayitno dan Erman Amti, Dasar-Dasar bimbingan dan Konseling, Jakarta: Rineka Cipta, 2004.

Rusman, Model-Model PembelajaranMengembangkan Profesionalisme Guru edisi ke-2, Jakarta: Raja Grafindo Persada, 2014.

Sudjana, Nana, Penilaian Hasil Proses Belajar Mengajar. Bandung: Remaja Rosdakarya 2004.

Tohirin,Bimbingan dan Konseling di Sekolah dan Madrasah (Berbasis Integrasi), Jakarta: Raja Grafindo Persada, 2007. 